Brit. J vener. Dis. (1965), 41, 163.

\title{
FIVE SURFACE COLONY TYPES OBSERVED IN CULTURES OF CULTIVABLE MEMBERS OF THE FAMILY TREPONEMATACEAE*
}

\author{
BY \\ ALBERT W. HANSON AND GEORGE R. CANNEFAX \\ From the Treponemal Immunology Laboratory, Research and Development, Venereal Disease Research \\ Laboratory, Venereal Disease Branch, Communicable Disease Center, U.S. Public Health Service, Atlanta, \\ Georgia
}

During the 58 years since Muhlens and Hartmann (1906) first reported the cultivation of anaerobic Treponemataceae in vitro, little has been accomplished in classifying these organisms other than by morphological description. A major obstacle to systematic classification has been the difficulty encountered in cultivating these organisms in general and as surface colonies in particular. Breed, Murray, and Smith (1957) list 38 species of Treponemataceae of which fifteen are said to have been cultivated in vitro. There are no descriptions of colony forms of any of the species.

Gates (1923) first described the cultivation from broth culture of four strains or species as surface colonies on blood agar plates incubated in a Brown anaerobic jar. Gates also reported that subculture from surface colonies was not always successful. Other reports citing similar results are those of Fortner (1929), Aksjanzew-Malkin (1933), Wichelhausen and Wichelhausen (1942), and Berger (1958).

Socransky, Macdonald, and Sawyer (1959) consistently obtained growth of oral treponemes as surface colonies only in cultures that were inoculated and incubated under strict anaerobic conditions but not in cultures inoculated at the bench under the normal atmospheric environment. It was concluded that exposure to atmospheric oxygen for the brief period required to inoculate the plates and subsequently to establish anaerobic conditions was detrimental to their growth as surface colonies.

Hardy, Lee, and Nell (1963) reported that surface colonies were obtained on streak plates with fourteen treponemal strains and one Borrelia strain inoculated under normal atmospheric conditions. Anaerobic conditions were rapidly established after inoculation. They hypothesized that established stock strains had

* Received for publication February 15, 1965. become adapted to artificial media and therefore produced surface colonies more readily than recently isolated strains, indicating that this adaptation is nutritional rather than environmental in relation to the presence or absence of oxygen.

The purpose of this report is to describe the colony morphology observed with 47 strains or species of treponemes and one strain of Borrelia.

\section{Material and Methods}

Taxonomic cultural studies of other organisms have shown that the morphological characteristics of organisms or the colonies produced by these organisms can be altered by variations in cultural conditions, such as the composition of the medium, temperature of incubation, and length of incubation time (Lubinski, 1894; Sevag and Green, 1944; Cavallo and Falcone, 1953; Price and Kneeland, 1954; Johnston, 1956; Kooistra and Sellers, 1957).

To satisfy the requirements of standardized conditions, the medium used throughout the study was of the same composition. It consisted of 45 per cent. spirolate broth (BBL), 45 per cent. brain heart infusion broth (BBL) fortified with 0.05 per cent. sodium thioglycollate, and 10 per cent. inactivated normal rabbit serum $\left(56^{\circ} \mathrm{C}\right.$. for 30 minutes). The medium has been found in other studies to be adequate for growth of several spiral organisms including those in this report (Tauber, Cannefax, Hanson, and Russell, 1962). Agar in a final concentration of $2 \cdot 5$ per cent. was used for all streak plates. Agar concentrations of less than 2.5 per cent. permitted some of the strains to develop submerged colonies which varied in morphology in relation to the agar concentration.

To allow for adequate evaporation of the water of syneresis before inoculation, the plates were held at room temperature for 18 to 24 hours with the covers ajar. The plates were streaked with actively motile organisms in the normal atmosphere, placed in a Brewer jar in the inverted position, and evacuated and refilled three times with a mixture composed of 95 per cent. hydrogen and 5 per 
cent. carbon dioxide. Any residual oxygen was reacted with the hydrogen gas by activating the catalyst in the Brewer lid. 5 per cent. carbon dioxide has been found to be necessary for the growth of some of the organisms included in this report. Plates were incubated at $35^{\circ} \mathrm{C}$. for 7 to 8 days.

Photographs of the colonies were taken with overhead lighting to permit the greatest resolution of the colonial morphology. The intense ring of light observed in some of the photographs is an artefact produced by this photographic technique. Oblique light did not reveal the fine structure of morphology so well as overhead lighting.

\section{Results}

Colonies produced by the majority of the 48 strains or species of Treponemataceae included in this study can be divided into five types when cultivated under the standardized conditions of this study.

Type I.-Colonies are circular in form, 1 to $3 \mathrm{~mm}$. in diameter, greyish and slightly opaque in colour, pulvinate in elevation, with entire margins (Fig. 1).

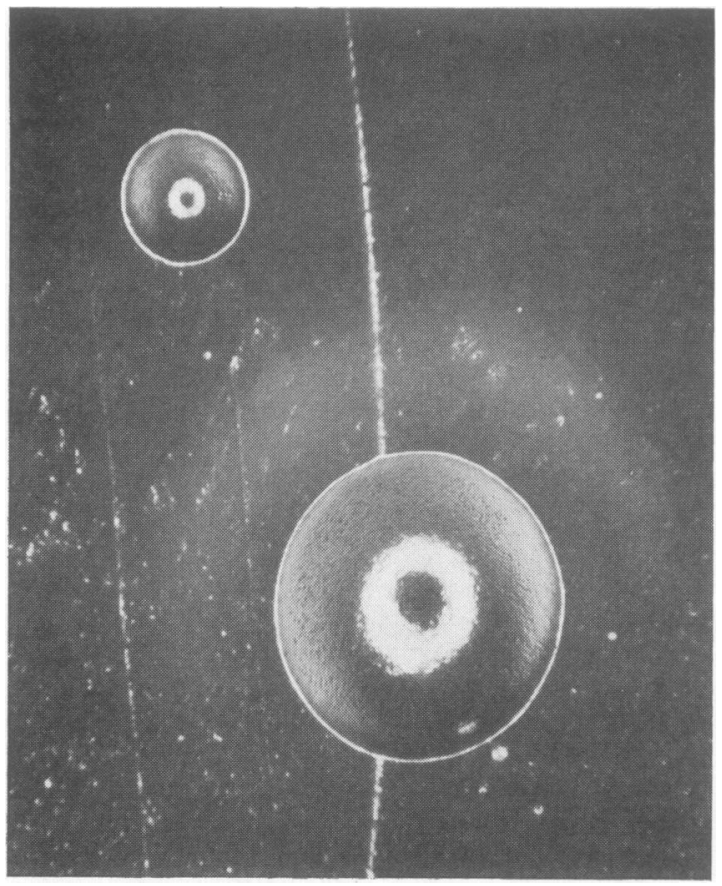

FIG. 1.-Colonies of Type I.

Type II.-Morphology of the colonies is the same as Type I except that the elevation is convex and the margins undulated (Fig. 2).

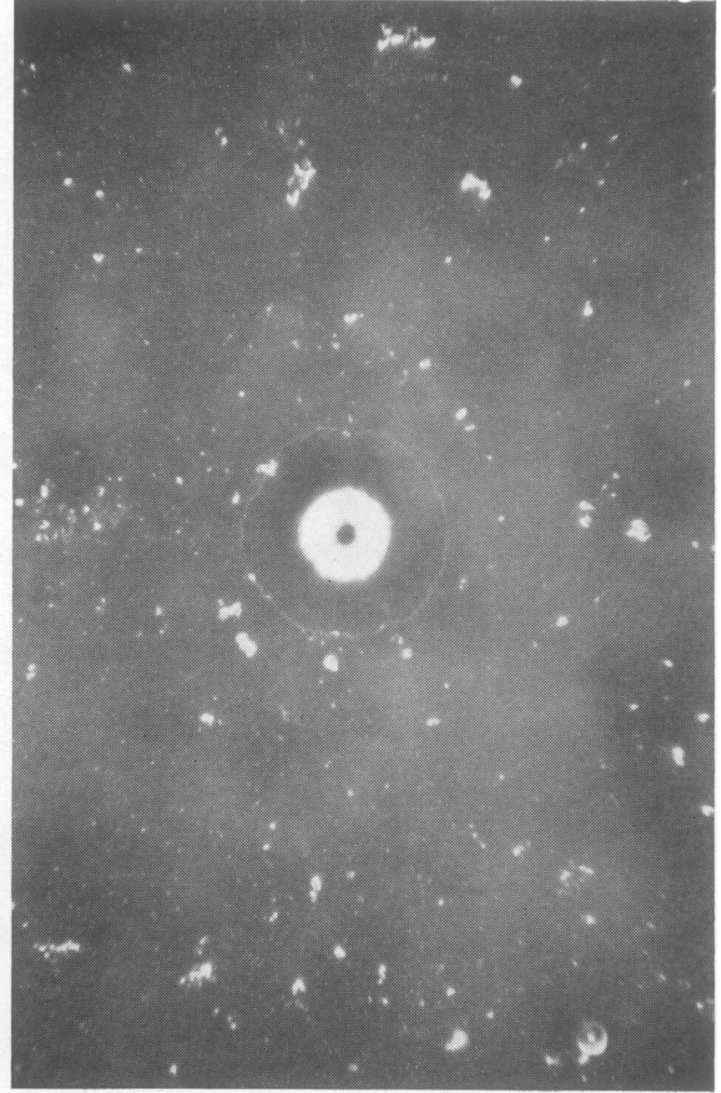

FIG. 2.-Colony of Type II.

Type III.-Colonies are irregular in form, umbonate in elevation, with entire margins, greyish and slightly opaque in the raised portion, but water-clear in the area surrounding the raised portion (Fig. 3, opposite).

Type IV.-Colonies are irregular in form, yellowish to grey in colour, slightly opaque, umbonate in elevation, with undulated margins Fig. 4, opposite).

Type V.-Colonies are irregular in form, 3 to $5 \mathrm{~mm}$. in diameter, no appreciable elevation, with entire margins, and water-clear in colour. A satisfactory photograph of this colony type could not be obtained.

The Table (p.166) shows the colony types observed with 48 species or strains of Treponemataceae used in this study. 


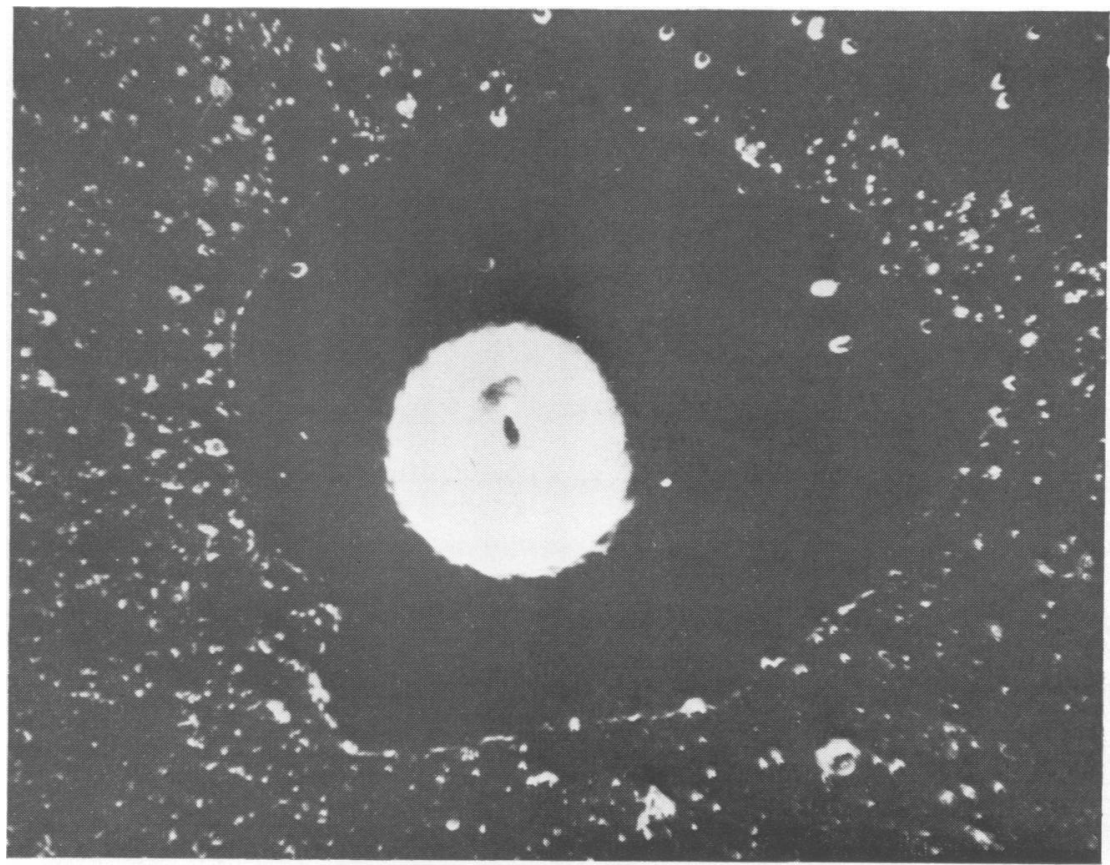

FIG. 3.-Colony of Type III.

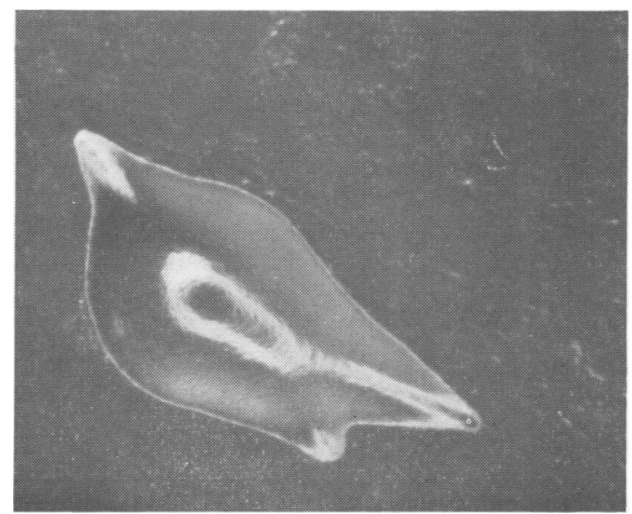

FIG. 4.-Colony of Type IV.

The five types of colonial morphology observed were stable upon direct subculture from the streak plates. When a colony was transferred to broth medium and subcultured ten or more times, the organisms developed the same type of colonial morphology as the parent colony when transplanted to agar plates.

Colonies of the Kazan strains exhibited a tendency to migrate along the inoculation lines of the streak plates. This tendency was not observed with any of the other organisms.

\section{Discussion}

Before a system for classification of spiral organisms by colonial types can be established for the different strains or species, agreement must be reached concerning which type of colonial morphology exhibited by the different strains is the prototype. For example, is Type I the prototype for Reiter cultures and Types III and IV subtypes of Reiter, or should they be established as separate entities?

If a classification were to be established using colonial morphology as a criterion, it is apparent that this could be at variance with the present classification in some instances. For example, the Noguchi and Nichols strains of $T$. pallidum and several of the initial isolates of treponemes from clinical material have a colonial morphology more similar to the Borrelia vincentii strain tested than to the other strains of treponemes included in this study.

The date of the isolation of some of the organisms in this study and the initial colonial morphology exhibited by the organisms under consideration is not known. It can be postulated, however, that, if changes in colonial morphology occurred during prolonged cultivation, they were of low incidence or occurred during longer periods of time than the organisms in this study were under observation.

Colonial types were not found to change during the one year in which these studies were made. The 
TABLE

COLONY TYPES PRODUCED BY STRAINS OR SPECIES OF TREPONEMATACEAE

\begin{tabular}{|c|c|c|c|c|c|c|}
\hline \multicolumn{2}{|c|}{ Strain or Species } & Type & $\begin{array}{c}\text { Type } \\
\text { III }\end{array}$ & $\begin{array}{c}\text { Type } \\
\text { III }\end{array}$ & $\begin{array}{l}\text { Type } \\
\text { IV }\end{array}$ & Type \\
\hline \multicolumn{2}{|c|}{ 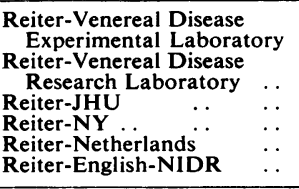 } & $\begin{array}{l}\times \\
\times \\
\times \\
\times \\
\times \\
\times \\
\times\end{array}$ & & $x$ & $\times$ & \\
\hline \multicolumn{2}{|c|}{ 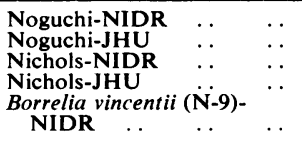 } & $x$ & & & & $\begin{array}{l}\times \\
\times \\
\times \\
\times \\
\times \\
\times \\
\times\end{array}$ \\
\hline \multicolumn{2}{|c|}{ 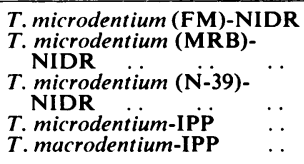 } & $\begin{array}{l}x \\
x\end{array}$ & & & $\times$ & \\
\hline \multicolumn{2}{|c|}{$\begin{array}{l}\text { Ichelson Treponemes } 1,2, \\
\text { and } 3 \text {. } \\
\text { Kazan-NIDR } \\
\text { Kazan Strains 2, 4, and }\end{array}$} & $\begin{array}{l}x \\
\times \\
\end{array}$ & $x$ & & $\times$ & \\
\hline \multicolumn{2}{|c|}{$\begin{array}{l}\text { T. refringens-IPP } \\
\text { T. trimerodonta-IPP } \\
\text { T. skoliodonta-IPP.. } \\
\text { T. calligyra-IPP } \quad \ldots \\
\text { T. minutum-IPP } \ldots \\
\text { T. comondoni-IPP } \ldots \\
\text { T. phagedenis-IPP .. }\end{array}$} & $\begin{array}{l}\times \\
\times\end{array}$ & & & $\begin{array}{l}\times \\
\times \\
\times \\
\times \\
\times\end{array}$ & \\
\hline \multicolumn{2}{|l|}{ T. zuelzerae.. } & $x$ & & & & \\
\hline $\begin{array}{l}\text { Isolates of } \\
\text { Treponemes } \\
\text { from } \\
\text { Genital } \\
\text { Lesions }\end{array}$ & $\begin{array}{l}\text { Patient No. } 2 \\
\text { Patient No. } 6 \\
\text { Patient No. } 8 \\
\text { Patient No. } 9 \\
\text { Patient No. } 12 \\
\text { Patient No. } 16 \\
\text { Patient No. } 17 \\
\text { Patient No. } 18\end{array}$ & $\begin{array}{l}\times \\
\times \\
\times \\
\times \\
\times \\
\times \\
x \\
\times \\
x \\
x\end{array}$ & $\begin{array}{l}x \\
\times \\
\times\end{array}$ & $\begin{array}{l}\dot{x} \\
\dot{x} \\
x\end{array}$ & & $\begin{array}{l}x \\
\times \\
x\end{array}$ \\
\hline
\end{tabular}

different types of colonies observed at the time they were first transplanted from liquid to solid medium could have been the result of mutants spontaneously appearing after long periods of cultivation in liquid medium or of multiple clones existing since the primary isolation of the strain. In this study, isolations made directly from clinical material have shown more than one type of colony at the time of initial isolation from given patients. Whether the different types of colony from these patients represent cultural variants of a single species or represent different species remains to be determined. In view of the methods that are known to have been used for the isolation of some of the strains (growth away from the contaminating commensal organisms in a gelled medium), multiple isolations could have been made.

Reiter protein antigens prepared according to the method of d'Alessandro and Dardanoni (1953) often resulted in antigens giving different patterns in serological and biochemical assays (Cannefax, 1963). The possibility existed that Reiter treponeme cultures were composed of more than one serological and cultural type. It has been found during this study that more than one type of colony is present in Reiter treponeme cultures in our own cultural lines and in cultural lines obtained from other laboratories. The relationship of serologically active components and colonial types has not been determined.

The medium used in this study, plus 20 units polymyxin B sulphate per millilitre, was found to be adequate for the isolation of treponemes as surface colonies from clinical material obtained from genital lesions, but not completely satisfactory for isolation of oral spirochaetes and Borrelia. These observations are similar to those of Socransky and others (1959) and Hardy and others (1963).

It was found that the length of time from streaking the plates to the establishment of anaerobic conditions in the Brewer jar could be prolonged for approximately 4 hours and resulted in good growths of surface colonies. Colonies of treponemes other than oral treponemes exposed to atmospheric conditions for more than $\mathbf{2 4}$ hours usually developed colonies or grew in broth when subcultured.

When the water of syneresis was not adequately evaporated from the plates before use, some of the organisms grew as spreading colonies on the agar surface, or as partially submerged diffusing colonies, or as completely submerged diffusing colonies. These variable types of colony are not observed on adequately dried plates. This example of variation of colonial morphology related to cultural conditions indicates the need for standardized cultural conditions for comparing colonial types produced by various strains or species.

\section{Summary}

48 strains or species of Treponemataceae have been grown as surface colonies under controlled cultural conditions. Certain strains exhibited more than one type of colonial morphology when initially transplanted from broth to agar plates. Individual colonial forms which have been observed for one year have been found to be stable upon direct subculture as surface colonies or after repeated subculture in broth medium.

It has been demonstrated that there are at least five colonial types among 47 strains of cultivable treponemes and one strain of Borrelia. Further studies may lead to the establishment of colonial types which would be of value in the further systematic classification of these organisms. 
The authors express their appreciation to J. F. Smith and D. L. Douglas for their technical assistance throughout these studies. Photographs of the surface colonies were taken by J. P. Gust, Jr., of the National Medical Audiovisual Facilities of the Communicable Disease Center, U.S. Public Health Service, Atlanta, Georgia.

We are very grateful to Dr John H. Tiedemann, Fulton County Health Department, Atlanta, Georgia, for supplying the clinical specimens from which treponemes were isolated in this laboratory, designated Patients $2,6,8,9,12,16,17$, and 18 in the Table.

Cultures of organisms used in these studies were obtained from the following:

J. Pillot (Institut Pasteur, Paris)

$\begin{array}{lll}T . \text { microdentium } & T \text {. minutum } & \text { T. trimerodonta } \\ \text { T. comondoni } & \text { T. macrodentium } & \text { T. phagedenis } \\ \text { T. skoliodonta } & \text { T. refringens } & \text { T. calligyra } \\ & \text { Reiter } & \end{array}$

Cultures designated IPP in Table.

P. H. Hardy (Johns Hopkins University)

Reiter Kazan strains numbered 2, 4, 5, and 8

Nichols Noguchi

Cultures designated $\mathrm{JHU}$ in Table.

E. G. Hampp (National Institute for Dental Research, National Institutes of Health)

T. microdentium (FM) Noguchi

T. microdentium $(\mathrm{N}-39) \quad$ Kazan

T. microdentium (MRB) Reiter - English

Nichols

Borrelia vincentii (N-9)

Cultures designated NIDR in Table.

New York City Health Department (New York)

Reiter Cultures designated NY in Table.

J. H. Bekker (Utrecht, The Netherlands)

Reiter

Culture designated Netherlands in Table.

H. Veldkamp (Wageningen, The Netherlands) T. zuelzerae

Sylvana Chemical Company (Orange, New Jersey) Ichelson cultures 1.2 , and 3

\section{REFERENCES}

Aksjanzew-Malkin, S. (1933). Zbl. Bakt., I Abt. Orig. 129,405

Berger, U. (1958). Beitr. Hyg. Epidem., No. 12, p. 1.

Breed, R. S., Murray, E. D. G., and Smith, N. R. (1957). "Bergey's Manual of Determinative Bacteriology", 7th ed. Williams and Wilkins, Baltimore.

Cannefax, G. R. (1963). Brit. J. vener. Dis., 39, 121.

Cavallo, G., and Falcone, G. (1953). Riv. Ist. sieroter. ital. 28, 455 .

d'Alessandro, G., and Dardanoni, L. (1953). Amer. J. Syph. 37, 137.

Fortner, J. (1929). Zbl. Bakt., I Abt. Orig., 110, 233.

Gates, F. L. (1923). J. exp. Med., 37, 311.

Hardy, P. H., Lee, Y. C., and Nell, E. E. (1963). J. Bact., 86,616

Johnston, J. A. (1956). Tex. Rep. Biol. Med., 14, 74.

Kooistra, J. A., and Sellers, W. (1957). Bact. Proc., 57, 98.

Lubinski, W. (1894). Zbl. Bakt., I. Abt. Orig., 16, 769.

Muhlens, P., and Hartmann, M. (1906). Z. Hyg. Infekt.$k r ., 55,81$.

Price, K. M., and Kneeland, Y., Jr. (1954). J. Bact., 67, 472.

Sevag, M. G., and Green, M. N. (1944). Ibid., 48, 469.

Socransky, S., Macdonald, J. B., and Sawyer, S. (1959). Arch. oral Biol., 1, 171.

Tauber, H., Cannefax, G. R., Hanson, A. W., and Russell, H. (1962). Exp. Med. Surg., 20, 324.

Wichelhausen, O. W., and Wichelhausen, R. H. (1942). J. dental Res., $21,543$.

Observation de 5 types de colonie de surface dans la culture de membres cultivables de la famille des tréponèmes

\section{RÉSUMÉ}

On a fait pousser 48 souches ou espèces de tréponèmes à l'étât de colonies de surface dans des conditions de culture contrôlées. Certaines souches montrèrent plus d'un type de morphologie coloniale quand elles furent transplantées du bouillon de culture aux boîtes de gelose. On a trouvé que des formes coloniales individuelles observées pendant 1 an pouvaient maintenir leur type, aussi bien lorsqu'elles furent repiquées directement en colonies de surface qu'après de nombreux repiquages en bouillon de culture.

On a prouvé qu'il y a au moins cinq types de colonies parmi les 47 souches de tréponèmes cultivables et une souche de Borrelia. Des études supplémentaires peuvent mener à l'établissement de types de colonies qui auraient une importance dans une classification systématique plus poussée de ces organismes. 